\title{
Mediterranean White Lupin Landraces as a Valuable Genetic Reserve for Breeding
}

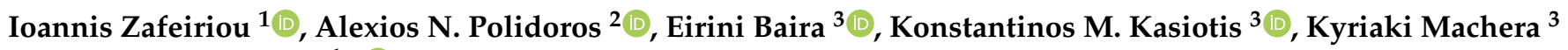 \\ and Photini V. Mylona ${ }^{1, *(\mathbb{D})}$ \\ 1 Institute of Plant Breeding \& Genetic Resources, HAO-DEMETER, 57001 Thermi, Greece; \\ zafeirioannis@gmail.com \\ 2 Laboratory of Genetics and Plant Breeding, School of Agriculture, Aristotle University of Thessaloniki, \\ 54124 Thessaloniki, Greece; palexios@agro.auth.gr \\ 3 Laboratory of Pesticides' Toxicology, Department of Pesticides Control and Phytopharmacy, \\ Benaki Phytopathological Institute, 8 St. Delta Street, Kifissia, 14561 Athens, Greece; e.baira@bpi.gr (E.B.); \\ k.kasiotis@bpi.gr (K.M.K.); k.machera@bpi.gr (K.M.) \\ * Correspondence: phmylona@nagref.gr; Tel.: +30-2310-478-904
}

Citation: Zafeiriou, I.; Polidoros, A.N.; Baira, E.; Kasiotis, K.M.; Machera, K.; Mylona, P.V. Mediterranean White Lupin Landraces as a Valuable Genetic Reserve for Breeding. Plants 2021, 10, 2403. https://doi.org/10.3390/ plants10112403

Academic Editor: Changsoo Kim

Received: 28 September 2021

Accepted: 4 November 2021

Published: 7 November 2021

Publisher's Note: MDPI stays neutral with regard to jurisdictional claims in published maps and institutional affiliations.

Copyright: (c) 2021 by the authors. Licensee MDPI, Basel, Switzerland. This article is an open access article distributed under the terms and conditions of the Creative Commons Attribution (CC BY) license (https:// creativecommons.org/licenses/by/ $4.0 /)$.

\begin{abstract}
Legumes crops are important for sustainable agriculture and global food security. Among them white lupin (Lupinus albus L.), is characterized by exceptional protein content of high nutritional value, competitive to that of soybean (Glycine max) and is well adapted to rainfed agriculture. However, its high seed-quinolizidine alkaloid (QA) content impedes its direct integration to human diet and animal feed. Additionally, its cultivation is not yet intensive, remains confined to local communities and marginal lands in Mediterranean agriculture, while adaptation to local microclimates restrains its cultivation from expanding globally. Hence, modern white lupin breeding aims to exploit genetic resources for the development of "sweet" elite cultivars, resilient to biotic adversities and well adapted for cultivation on a global level. Towards this aim, we evaluated white lupin local landrace germplasm from Greece, since the country is considered a center of white lupin diversity, along with cultivars and breeding lines for comparison. Seed morphological diversity and molecular genetic relationships were investigated. Most of the landraces were distinct from cultivars, indicating the uniqueness of their genetic make-up. The presence of pauper "sweet" marker allele linked to low seed QA content in some varieties was detected in one landrace, two breeding lines, and the cultivars. However, QA content in the examined genotypes did not relate with the marker profile, indicating that the marker's predictive power is limited in this material. Marker alleles for vernalization unresponsiveness were detected in eight landraces and alleles for anthracnose resistance were found in two landraces, pointing to the presence of promising germplasm for utilization in white lupin breeding. The rich lupin local germplasm genetic diversity and the distinct genotypic composition compared to elite cultivars, highlights its potential use as a source of important agronomic traits to support current breeding efforts and assist its integration to modern sustainable agriculture.
\end{abstract}

Keywords: lupin; Mediterranean; genetic diversity; marker assisted selection; traits; alkaloids; metabolomics

\section{Introduction}

White lupin (Lupinus albus L.) is considered one of the most important domesticated lupin species, when regarding the nutritional value of seeds [1]. Characterized by its protein-rich composition (up to $44 \%$ of the total dry mass), a high-quality fatty-acids profile, and a plethora of health-promoting bioactive molecules, white lupin denotes a nutritional treasure worthy to be harnessed [2,3]. However, antinutritional compounds like quinolizidine alkaloids (QA) present in high contents in wild white lupin populations and bitter cultivars, reduce its nutritional value and prevent the use of unprocessed seeds for human and animal consumption. From an agronomic perspective, white lupin promotes 
both $\mathrm{N}$ - and P- soil enrichment, through the formation of nodules and proteoid roots [4], and can be cultivated under rainfed intercropping systems, encouraging low-input farming systems [5-7]. Therefore, it suggests a promising choice for promoting global food security and environmental protection, through sustainable agriculture [8].

White lupin originates in the southern Balkans, and "graecus-type" natural populations disperse throughout the Eastern Mediterranean basin, where landraces are used for human consumption and fodder, dating back to 2000BC [9]. However, because of its adaptability to marginal regions, and the requirement of a post-harvest debittering process [10], white lupin's cultivation was restricted mainly to local communities on barren lands. Currently, lupins account for only $1 \%$ of the main grain legumes cultivated worldwide. Lupin production and cultivated area worldwide for 2019 was estimated at about $1,006,842$ tonnes and 887,111 ha, respectively. Australia is the largest producer, with $47.1 \%$ of the global production, while Europe is second (39\%) according to FAOSTAT [11]. In Europe L. angustifolius L. and L. luteus L. are the predominant cultivated species in the north and countries with more than 10,000 ha of lupins are Poland, the Russian Federation, Germany, Belarus, and Ukraine. In the south, where L. albus L. is predominant, Italy (5000 ha), France (3600 ha), and Spain (3045 ha) are the main lupin-producing countries [12].

Modern breeding efforts to improve white lupin agronomic characteristics are very recent [9]. Thus, there is still significant variability even among commercial germplasm for the most essential breeding targets, namely, the seed's nutritional value [13] and the toxic, bitter secondary metabolites QAs $[14,15]$. The total alkaloid content in white lupin varies from 0.02 to $12.73 \%$ of the seed's dry weight. Cultivars possessing the pauper gene contain $0.02-0.05 \%$ alkaloids of the seed dry weight [16]. The recently published white lupin pangenome study demonstrated that pauper locus has a key role in the species domestication and breeding [17].

Other important agronomic characters of white lupin, which attracted the breeders' attention, are vernalization insensitivity [18], anthracnose resistance [19], yield stability [20], and abiotic-stress acclimation [21].

White lupin's global commercial potential has incited the breeding interest to focus not only in yield boost, but also in expanding its cultivation to agroclimatic regions, other than the Mediterranean basin, as extreme climate-change-related phenomena push the cultivation of some crops northwards [22]. On top of that, restricted precipitation levels during spring and frequent dry spells, throughout the Mediterranean basin, as a consequence of climate change [23-25], have a detrimental impact on pollen fertility [26], pollinator-flower interactions $[27,28]$, pod filling, and seed development, resulting in premature harvesting and yield losses $[29,30]$. Vernalization insensitivity and flowering time in white lupin are controlled by a highly complex multi-locus system [18,31].

Anthracnose is a global fungal disease, responsible for devastating epidemics, characterized by significant yield losses [32-34]. Temperatures over $10^{\circ} \mathrm{C}$ and humid weather promote conidia germination, with $25^{\circ} \mathrm{C}$ being optimal for fungal growth; whereas dry summer conditions are favorable for the preservation of inoculum on unharvested plant tissues [35,36]. Colletotrichum lupini, is mostly identified as the responsible pathogen for lupin anthracnose. Nonetheless, it has been reported in several other crops such as olive [37]. The pathogen emerges as an alarming polyphagous phytopathogenic strain for the Mediterranean agriculture. White lupin breeding has been directed to the creation of elite anthracnose resistant cultivars, employing map construction, genomic screening, phenotyping tools, field experimentation, and generation of molecular markers, to detect anthracnose resistant accessions [19,38-41]. Thus far, Ethiopian landraces have been extensively studied, revealing a highly diverse germplasm and embodying unique loci that confer resistance to anthracnose [38,42].

Successful breeding significantly depends on the extent of the available genetic resourcesPhenotypic and molecular markers have already been used in few studies, to estimate the genetic diversity between wild and breeding white lupin germplasm, and to enable incorporation of potentially valuable alleles from distantly related wild accessions to 
the genetic pool of elite cultivars $[43,44]$. Additionally, molecular markers are continuously developed, for the effective selection of germplasm with desired traits [31,45]. Furthermore, genomic resources are now available in white lupin and their use will greatly advance our understanding of the species diversity. In such an effort, very recently genome sequences of 39 accessions were used to establish a white lupin pangenome that can be used as resource to identify genes linked to important agronomic traits and analyze genetic variability [17].

Although such progress will inevitably lead to development of more sophisticated tools to explore genetic variation in white lupin genetic resources, up to now SSR markers have been proved integral tools to investigate species diversity. The Balkan Peninsula represents a yet untapped germplasm diversity center for white lupin, concealing potentially valuable loci in landraces and natural populations that could promote adaptability to climate-change-relevant extreme conditions [46,47]. In this study we applied available SSR molecular markers linked to agronomically important traits and morphological seed characteristics to explore the genetic diversity of white lupin Greek landraces and compare it with that observed in commercial varieties and breeding lines. Results of the study may facilitate marker assisted breeding in white lupin and enable identification and introgression of valuable alleles into new elite cultivars.

\section{Results}

\subsection{Seed Morphological Characters}

All seed morphological characters' measurements were statistically analyzed and a summary of the statistics is shown in Table 1. The Multivariate Analysis of Variance indicated that all 45 accessions are distinguished from one another, when regarding their seed morphology, with statistical significance $(p=0.003)$. A Pearson's correlation matrix revealed strong correlation between seed area with TSW, perimeter and width (above 0.662) and between mean Gray Value with maximum and median Gray Value (above 0.709), suggesting, that a single character measurement is sufficient to represent highly correlated characters. Circularity showed only small to medium significant correlation with seed width, minimum, and mean and median Gray Value (above 0.323). Integrated density had a negative correlation with the rest of the variables, statistically significant only to height and width.

Table 1. Summary statistics of the seed morphological characters.

\begin{tabular}{|c|c|c|c|c|c|}
\hline Variable & Observations & Minimum & Maximum & Mean & Std. Deviation \\
\hline TSW (g) & 45 & 70.8 & 968.2 & 357.2 & 116.7 \\
\hline Area $\left(\mathrm{mm}^{2}\right)$ & 45 & 628.0 & 2317.2 & 963.2 & 260.5 \\
\hline Perimeter $(\mathrm{mm})$ & 45 & 304.5 & 578.8 & 374.1 & 42.2 \\
\hline Circularity $^{+}$ & 45 & 0.076 & 0.090 & 0.085 & 0.004 \\
\hline Height (mm) & 45 & 66.7 & 105.9 & 81.1 & 9.4 \\
\hline Width (mm) & 45 & 82.3 & 140.5 & 102.8 & 12.2 \\
\hline Gray Value ${ }^{\dagger}$ (Min.) & 45 & 0.000 & 102. & 46.1 & 27.5 \\
\hline Gray Value ${ }^{\dagger}$ (Max.) & 45 & 128.0 & 255. & 205.6 & 34.8 \\
\hline Gray Value $^{\dagger}$ (Mean) & 45 & 70.4 & 166.6 & 136.1 & 28.2 \\
\hline Gray Value $^{\dagger}$ (Median) & 45 & 65.0 & 169.0 & 137.0 & 28.7 \\
\hline Integrated Density ${ }^{\dagger}$ & 45 & $576,855.0$ & $23,398,105.0$ & $6,649,080.0$ & $6,775,359.0$ \\
\hline
\end{tabular}

${ }^{+}$Circularity is morphometric and gray value and integrated density are densitometric parameters that have no units.

Partitioning of the variance and grouping of the accessions, regarding seed morphology, were estimated by hierarchical clustering under the Unweighted Pair Group Method with Arithmetic mean (UPGMA) and Principal Component Analyses (PCA). The UPGMA analysis gave formation to a three cladded dendrogram (Figure 1), with most of the landraces grouped together in one clade, along with some of the cultivars that were separated in subclades. A particular landrace, GR2, presenting unique seed morphology formed a single clade alone. A third clade consisted exclusively of cultivars and breeding lines. A PCA performed to calculate the Eigenvalues and variability partitioning to the 
different vectors, with the first two dimensions explaining $61.92 \%$ of the data variability. In a bi-plot graph of the PCA, the genotypes that were found to be highly correlated, are in close proximity with one another, and the distribution of the accessions forms two groups, with GR2 being an outlier (data not shown). Regarding the seed surface, landraces GR24, GR25, GR27, and GR28 have biconcave seeds of orange-white color, with dark flecks and a characteristic black line peripheral to the hilum, while the rest of the accessions have white-yellowish seeds with no spot pattern (online Supplementary Figures S3-S6).

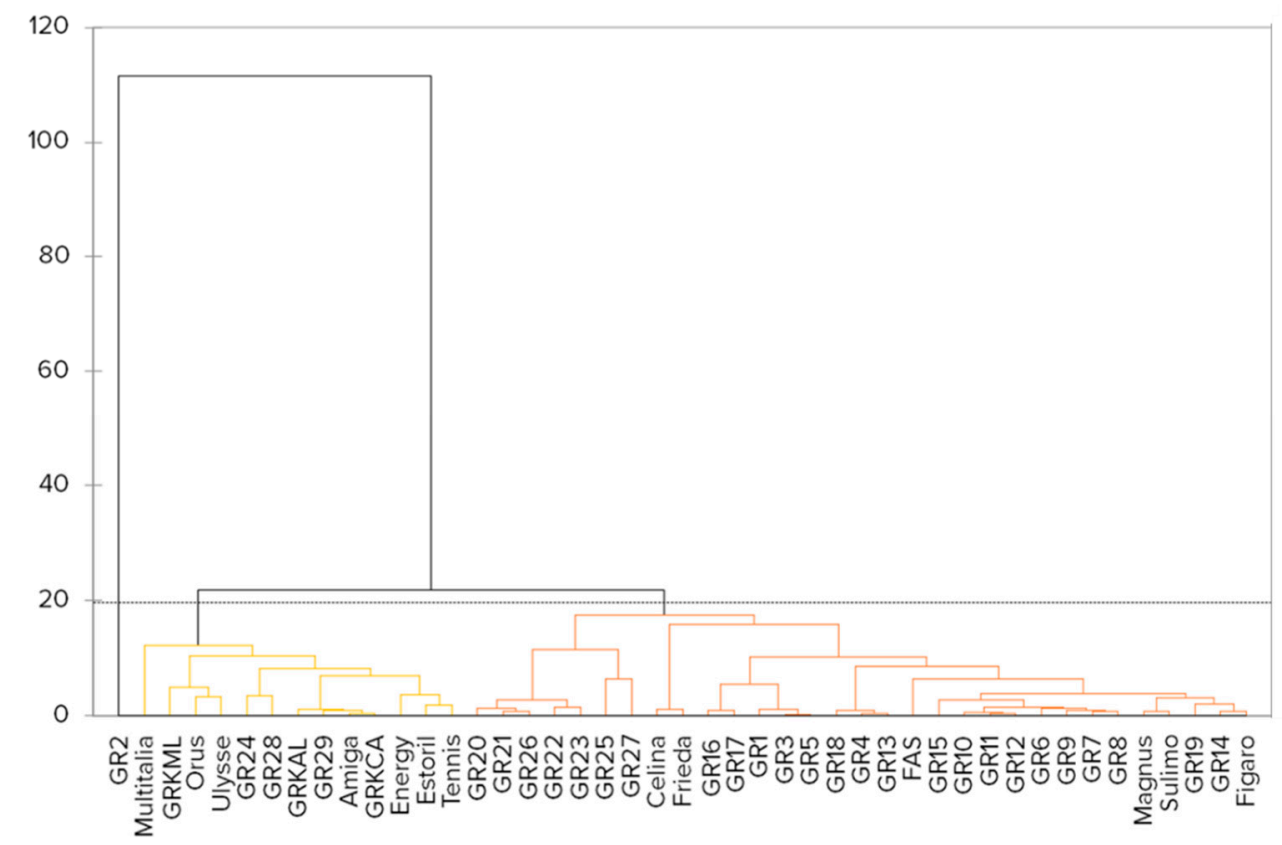

Figure 1. UPGMA dendrogram based on the Euclidean distance of the morphological markers of the white lupin accessions' seeds.

\subsection{Markers for Genetic Analysis}

The molecular marker HRM analysis elucidated 53 distinct allelic patterns, which were assumed as different genotypes. The marker PIC values (Polymorphic Information Content) ranged from 0.1 for GI-F1 to 0.8 for LSSR06a and LSSR41, with an average of 0.5 (online Supplementary Table S1). In order to statistically analyze the results, a binary matrix was constructed, based on the allelic patterns generated from the HRM analysis, where " 1 " indicate the presence of a specific allelic pattern, and " 0 " indicate its absence. To that binary matrix the results of the presence or absence of the alleles for anthracnose, vernalization and alkaloid biosynthesis were also incorporated.

Based upon this matrix, we calculated the Nei's genetic distance among all samples and formed a circular dendrogram, according to UPGMA clustering (Figure 2). As presented in the dendrogram, the whole germplasm is divided in three major clades. Clade A consists of landraces originated from Andros island, while clade B incorporates most landraces from Northern Greece, Peloponnese, Lemnos island, and Leros island and the three breeding lines. Clade $\mathrm{C}$ encloses all the commercial cultivars along with all the landraces from Crete, one landrace from Andros, Lemnos, and Leros islands and one breeding line. Interestingly the Cretan landraces are sub-grouped into two subclades, one housing landraces (GR1, GR2, GR3 and GR20) and the other holding GR3 and Multitalia. Next to the later are landraces GR19 from Crete and GR6 from Leros island. While the breeding line GR29 is grouped together with six commercial cultivars in a subcluster.

Patterns of genetic relationships among the studied germplasm are visualized by PCoA analysis, with the first two axes explaining the $55.49 \%$ of the observed variance (Figure 3). Four distinguishable groups were formed, and genetically similar genotypes are enclosed within the red oval shapes. Genotypes within groups C and D show a narrow 
distribution on coordinate 1, while genotypes within groups A and B are more broadly distributed, indicating higher genetic variability encompassed within the landraces. The Mantel's test performed for inspecting the potential correlation among the genetic distances calculated by the seed morphology measurements and by molecular markers showed a non-significant low positive trend $(r=0.082, p=0.068)$. Possible associations of each morphological trait with the molecular markers were tested by linear regression analysis, but the results did not reveal any significant correlation.

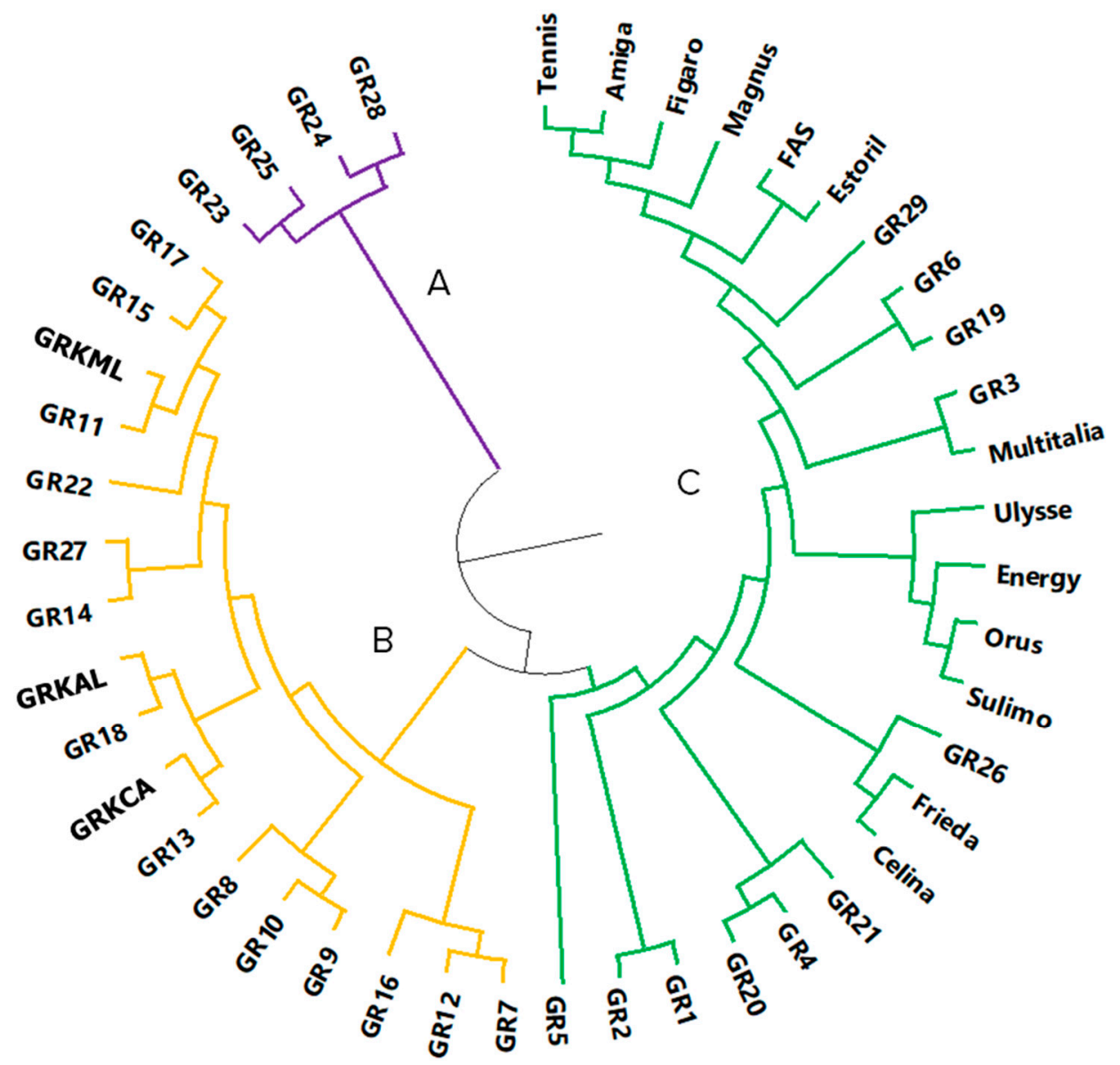

Figure 2. UPGMA dendrogram, clustering the accessions in three main clusters (A, B, and C).

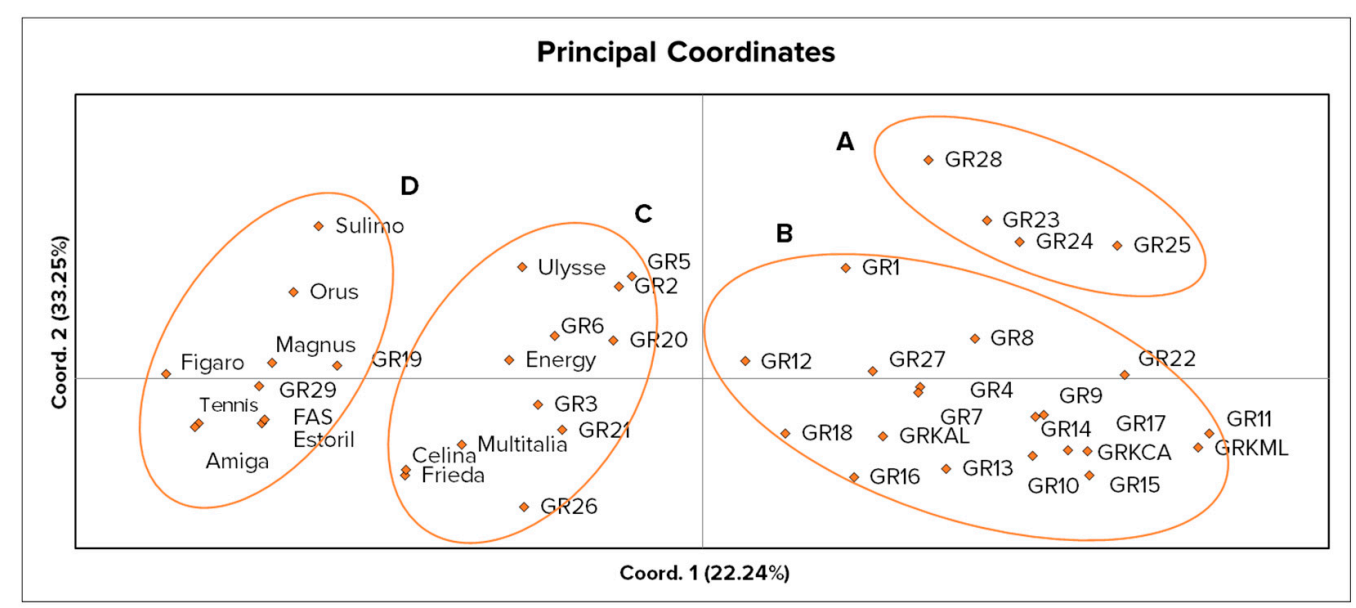

Figure 3. Two-dimensional PCoA analysis of 45 white lupin accessions. Representation of four non-overlapping groups (A-D) delimited by red ovals. 


\subsection{Marker Genotypes Linked to Significant Traits}

The 45 accessions under examination were further characterized for presence of marker alleles identified in other studies to be linked to agronomic traits important for white lupin breeding. For resistance to anthracnose, the accessions were screened with TP222136 and TP338761 molecular markers [18]. Most of the landraces, together with cultivars Frieda and Celina, possess the resistance-conferring antr04_1/antr05_1 locus allele, while landraces GR1, GR2, GR23, GR25, and cultivar Sulimo, carry the resistanceconferring antr04_2/antr05_2 locus allele (Table 2). Notably, landraces GR23 and GR25 from Andros island are the only landraces to hold both resistance-conferring alleles.

Regarding vernalization responsiveness, three molecular markers were used, capable of distinguishing between vernalization responsive and non-responsive genotypes, namely SEP3-F1, GI-F1, and FTa1-F1 [18]. Regarding SEPALLATA 3 locus, all cultivars apart from Sulimo, breeding line GR29, as well as landraces GR3, GR7, GR12, GR16, GR19, GR21, and GR26, bring upon the early flowering allele (Table 2). The FLOWERING LOCUS $T$ early flowering allele was present in all accessions, except for five, as in those cases, the aforementioned locus could not be detected using the specific primer set (Table 2). Regarding GIGANTEA locus, detection of the different alleles in agarose gel electrophoresis was inconclusive for GI-F1 marker, so the samples were subjected to Sanger sequencing (CeMIA SA, Larissa, Greece) in order to detect the restriction site of Acil, which was present in landraces GR5, GR10, and cultivar Frieda (Table 2). In order to investigate the presence of the "sweet" allele on pauper locus, LAGI01_35805_F1_R1 molecular marker was employed [48], revealing the probability of a low alkaloid genotype in all commercial varieties, GRKML and GRKAL breeding lines, as well as in GR26 landrace.

It is conceivable that presence of alleles linked with agronomic traits as identified in other studies, does not necessarily imply the same for the materials examined in this study. Consequently, any association of these alleles to the expected phenotypes must be confirmed before the markers can be further used for breeding purposes. Thus, the alkaloid profile of the accessions was further examined.

Table 2. Allele scoring on anthracnose resistance and early flowering. Symbol " + " indicates the presence and "- " indicates the absence of the marker alleles, that confer anthracnose resistance and early flowering, "**" indicates inconclusive allele detection.

\begin{tabular}{cccccc}
\hline \multirow{2}{*}{ Accession } & \multicolumn{2}{c}{ Anthracnose Resistance } & \multicolumn{3}{c}{ Early Flowering } \\
\cline { 2 - 6 } & TP222136 & TP338761 & GI-F1 & SEP3-F1 & FTa1-F1 \\
\hline GR1 & - & + & - & - & + \\
GR2 & - & + & - & - & + \\
GR3 & - & - & - & + & + \\
GR4 & + & - & - & - & + \\
GR5 & - & - & + & - & + \\
GR6 & - & - & - & - & + \\
GR7 & + & - & - & + & + \\
GR8 & + & - & - & - & + \\
GR9 & + & - & - & - & + \\
GR10 & + & - & + & - & + \\
GR11 & + & - & - & - & + \\
GR12 & - & - & - & + & + \\
GR13 & + & - & - & - & + \\
GR14 & + & - & - & - & + \\
GR15 & + & - & - & + & + \\
GR16 & + & - & - & + & + \\
GR17 & + & - & - & - & + \\
GR18 & + & - & - & - & + \\
GR19 & - & - & - & + & + \\
GR20 & - & - & - & $*$ & + \\
GR21 & + & - & - & + & + \\
\hline
\end{tabular}


Table 2. Cont.

\begin{tabular}{|c|c|c|c|c|c|}
\hline \multirow{2}{*}{ Accession } & \multicolumn{2}{|c|}{ Anthracnose Resistance } & \multicolumn{3}{|c|}{ Early Flowering } \\
\hline & TP222136 & TP338761 & GI-F1 & SEP3-F1 & FTa1-F1 \\
\hline GR22 & + & - & - & - & + \\
\hline GR23 & + & + & - & - & + \\
\hline GR24 & + & $*$ & - & $*$ & $*$ \\
\hline GR25 & + & + & - & - & * \\
\hline GR26 & + & - & - & + & + \\
\hline GR27 & + & - & - & - & + \\
\hline GR28 & - & * & - & - & $*$ \\
\hline GR29 & - & - & - & + & + \\
\hline GRKML & + & - & - & - & + \\
\hline GRKAL & + & - & - & - & + \\
\hline GRKCA & + & - & - & - & + \\
\hline Energy & + & - & - & + & + \\
\hline Magnus & - & - & - & + & + \\
\hline Orus & - & - & - & + & + \\
\hline FAS & - & - & - & + & + \\
\hline Estoril & - & - & - & + & + \\
\hline Ulysse & - & - & - & - & + \\
\hline Sulimo & - & + & - & + & + \\
\hline Figaro & - & - & - & + & + \\
\hline Multitalia & - & - & - & + & + \\
\hline Tennis & - & - & - & + & + \\
\hline Amiga & - & - & - & + & + \\
\hline Frieda & + & - & + & + & $*$ \\
\hline Celina & + & - & - & + & * \\
\hline
\end{tabular}

\subsection{Alkaloid Content Profile}

The alkaloid profiling of accessions was investigated by Ultra-High Performance Liquid Chromatography coupled to Orbitrap High Resolution Mass Spectrometry Analysis (UHPLC-HRMS). Overall, the approach used allowed to tentatively annotate sixteen alkaloids, including angustifoline, lupinine, epilupinine, sparteine, etc. (online Supplementary Table S2) that are known to participate in the alkaloid profile of Lupinus albus L. seeds. A representative chromatogram of an accession of lupin seeds is presented in (online Supplementary Figure S1). Relative abundance of total alkaloids in landraces and two cultivars, namely Celina and Multitalia, is shown in Figure 4. Landraces are grouped in five groups (L-1, L-2, L-3, L-4 and L-5) according to their alkaloid abundance in comparison to the Celina cultivar that is a "sweet" variety exhibiting the lowest alkaloid content. It is noteworthy that Multitalia is a known bitter cultivar. Taken into account the alkaloid profile of the examined accessions we may conclude that the sole presence of the "sweet" pauper marker does not necessarily predict for a low alkaloid profile.

Interestingly the partitioning of the 16 alkaloid compounds assessed in each sample varied between accessions, indicating that each alkaloid biosynthesis product may accumulate in different amounts in different genotypes (online Supplementary Figure S2). Furthermore, landraces GR24, GR25, GR27, and GR28 with spotted seeds had no higher alkaloid content compared to those with white-yellowish seeds. Further studies implementing more specific markers of alkaloid biosynthesis pathways are required to complement systematically the seed alkaloid profile and the genetic alleles configuration of the genotype. Moreover, the partitioning of the 16 alkaloids in the metabolic profile of landraces is quite diverse indicating that a more thorough assessment of critical alleles that impart accumulation of alkaloids is necessary for an integrated assessment of valuable germplasm that could be underscored in the sole absence of the pauper allele. 


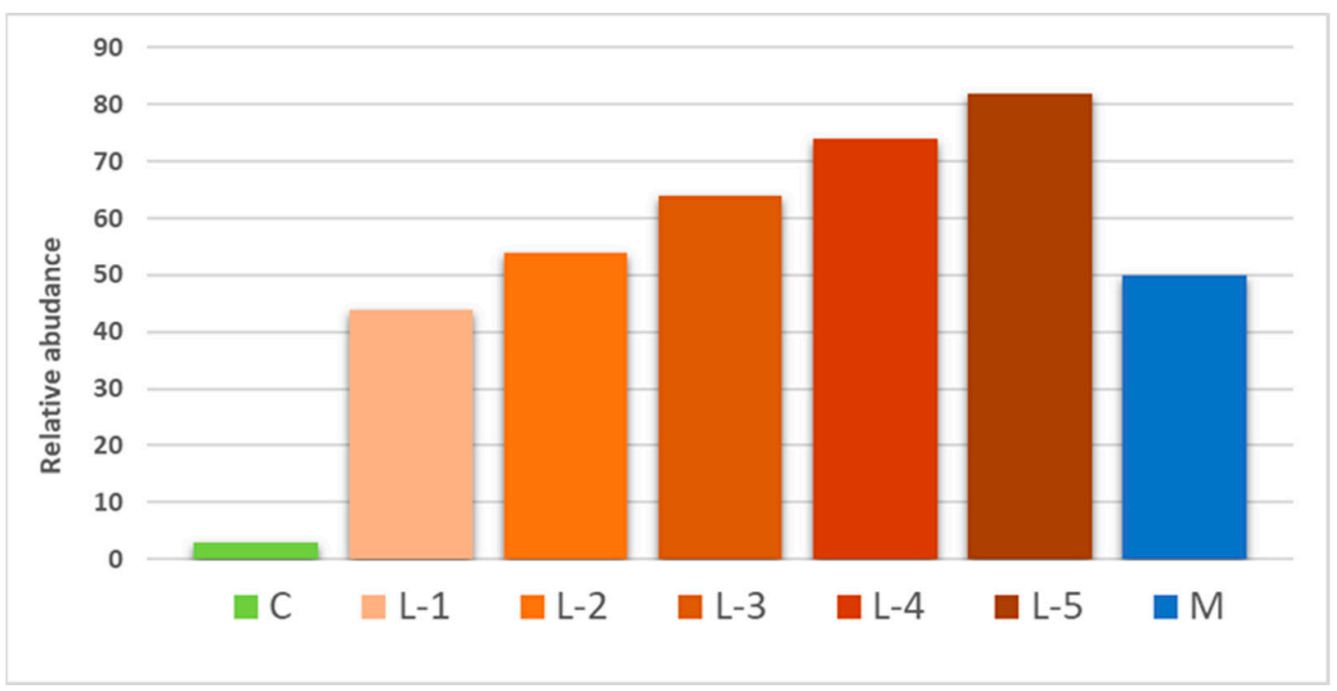

Figure 4. Relative alkaloid abundance in seed extracts of landraces grouped in five groups L-1 to L-5, according to the alkaloids abundance in comparison to cultivar Celina (C) and Multitalia (M).

\section{Discussion}

Genetic diversity of white lupin genetic resources in Greece was assessed using morphological and molecular markers. This is the first report for molecular characterization of local white lupin germplasm in a country that is considered as a center of genetic variation for this crop.

Seed morphological characteristics were selected because heritability of seed morphological traits and ease of access to seeds may provide a reasonable alternative to estimate the distribution of genetic variation [49]. Considerable variation was recorded for TSW, seed size, and coloration while less variation could be detected for circularity. Clustering of genotypes formed subclades consisted solely of landraces, although some landraces were partitioned with the cultivars. Other studies indicate high level of polymorphism for selected morphological traits in white lupin, while generally these characters are not very informative for landrace genetic diversity studies. Wide range of variation was recorded for proportion of pod walls and other pod components in 325 ecotypes originated from 17 countries of the Mediterranean region and north Africa. The variation was related with the country of origin of the accessions since Egyptian ecotypes had the lowest proportions of pod walls while the Greek and Italian ecotypes had the highest [50]. Analysis of Ethiopian landraces indicated the existence of high level of polymorphism for different agronomic traits and nutrient contents of grain [44]. In an extensive study of 35 Spanish white lupin accessions estimating variation for 50 quantitative and 51 qualitative characters, described in the literature as highly heritable, only a small number of three quantitative and one qualitative parameters were variable enough to provide good separation of the accessions [51].

It is conceivable that as valuable as they may be, agronomic traits and morphological characteristics as genetic markers are of limited resolution power for genetic diversity assessment, compared with molecular markers. In this study, molecular polymorphism was considerable. Relatively moderate to high PIC values, indicating a high level of genetic diversity in the germplasm assessed. The markers were suitable for discrimination of most landraces that clustered apart from the commercial cultivars indicating a unique diversity. Specifically, landraces were grouped into two clusters with those originated from Andros island forming a distinct group representing the wild graecus form of lupin, while all the others were grouped together regardless of geographic origin. Interestingly, all the commercial cultivars were grouped in one cluster.

Molecular markers have been proved valuable tools for germplasm diversity studies in many plant species. Yet, limited number of studies on white lupin molecular diversity are cited in the literature. To the best of our knowledge, genetic diversity using molecular markers has been estimated for local germplasm from Ethiopia [42,52] and Egypt [53]. 
Our results are consistent with the previous studies indicating high level of landrace accession polymorphism. Landraces from Ethiopia were highly polymorphic [43] and formed a distinct and separate grouping from Australian cultivars, breeding lines, and European cultivars, which cluster together, probably revealing their pedigree and breeding history [52]. Further development of molecular markers and application in genetic diversity studies could enhance our understanding of white lupin genetic resources and promote their use in modern breeding.

The Greek landscape is characterized by a mountainous terrain, with numerous peninsulas and islands, and is considered a hotspot of L. albus diversity. Such isolated regions, justify divergence of local landraces, explaining the finding that landraces from Andros and Lemnos islands and from Mani peninsula are clustered separately from the cultivars examined. Additionally, landraces from Andros island are distinctly diversified from the rest accessions, implying that Andros constitutes a genetic pool of unique genes, potentially useful for white lupin breeding.

Eventual exchange of landraces between Greek farmers and dispersal of their cultivation farther than their local point of origin may explain landrace sub-clusters on the dendrogram (Figure 2). It is also a common practice for smallholder farmers to use a portion of the seed yield for the next growing season, exclusively, or in mixtures with high yielding cultivars. Long periods of recycling the seed of a commercial variety, along with potential adaptation pressure and selection by the farmers, promote the generation of new variability, resulting in new landraces that are well adapted to the specific geoclimatic conditions and to their traditional management and uses [38,54,55]. Moreover, potential gene flow from neighboring white lupin cultivar crops could justify that landraces appear genetically in close proximity with commercial germplasm.

Quinolizidine alkaloids are predominantly found in high levels in natural populations and landraces, making lupin a repulsive choice for lambs and goats, that feed on pasture [56]. That justifies the presence of white lupin natural populations throughout uncultivated lands, that shelter underutilized genetic diversity. QA biosynthesis occurs in the vegetative upper part of the plant, and they are subsequently transported to the seeds. Modern breeding strategies focus on creating elite cultivars, with low alkaloid content (below $0.02 \%$ of the total dry weight) [15], as well as cultivars that retain QAs in vegetative tissues, thus producing hardy plants with "sweet" seeds [15]. Their biosynthesis is regulated by five different loci, with pauper being thoroughly investigated thus far, on account of its contribution to QA synthesis regulation $[38,48,57]$. Regarding the accessions under examination, the "sweet" pauper marker was detected in all cultivars, in breeding lines GRKML and GRKAL, and in GR26 landrace. Absence of the "sweet" pauper marker from the vast majority of the landraces is in accordance with their high QA content. However, presence of the marker in high QA genotypes, like the cultivar "Multitalia", makes this marker a weak predictor of low QA content with broad applicability.

In Mediterranean farming systems, white lupin is considered a winter crop and sowing takes place in autumn, in order for the crop to take advantage of the late winter rainfalls. Thus, sufficient seed filling is succeeded before the early dry spells that occur in May, which have been more frequent and severe in Mediterranean ecosystems, due to the climate change [24]. Early flowering is considered to be an effective stress escape mechanism, in that it promotes fulfillment of the plants biological cycle, prior to terminal drought stress [46,58]. Additionally, genotypes non-responsive to vernalization, suggest crops suitable for spring sown cultivation, in northern regions, with long lasting winter. While white lupin germplasm native to the Balkan peninsula has been previously characterized as vernalization responsive $[59,60]$, among the local landraces under investigation, GR3, GR7, GR12, GR16, GR19, GR21, and GR26 hold both SEPALLATA 3 and FLOWERING LOCUS T early flowering alleles, implying a vernalization independence-promoting regional microclimate at the collection sites [31,60]. Moreover, the early flowering allele of SEPALLATA 3 was detected in all commercial varieties, except for Ulysse. The inability of FTa1 primer set to hybridize in three landraces from Andros island and in cultivars Frieda and Celina, 
suggest contingent mutations located at the primer binding site, in the genomes of those accessions (Table 2). The GIGANTEA early flowering promoting allele was detected only in GR5, GR10, and Frieda cultivar. However, further experimentation on the aforementioned landraces is needed, in order to examine the predictive power of those molecular markers, and their potential implementation in white lupin breeding programs.

Alleles that confer resistance to anthracnose, were previously found only in Ethiopian landraces, which are distinctly related to European improved germplasm [42]. Resistanceconferring alleles, located in antr04_1/antr05_1 and antr04_2/antr05_2 loci, were also detected in the Greek landraces examined, with GR23 and GR25 from Andros, having both of them in their genome (Table 2). Summarizing these results, molecular markers linked to important agronomic traits have been identified in white lupin germplasm from the Greek rural areas. It will be significant to confirm the association of these markers to the relevant plant phenotype in further studies. This will be crucial for the utilization of the relative landraces when is necessary (e.g., stacking alleles present in one landrace), as sources of the responsible alleles in lupin breeding.

\section{Materials and Methods}

\subsection{Plant Material}

Seeds of 28 landraces were obtained by local farmers and collection expeditions in rural areas throughout the Greek territory (Figure 5). Four experimental breeding lines were provided by the Institute of Plant Breeding and Genetic Resources of the Hellenic Agricultural Organization-DEMETER. Thirteen commercial varieties were provided by local representatives of the seed companies. Details on plant material are given in Table 3.

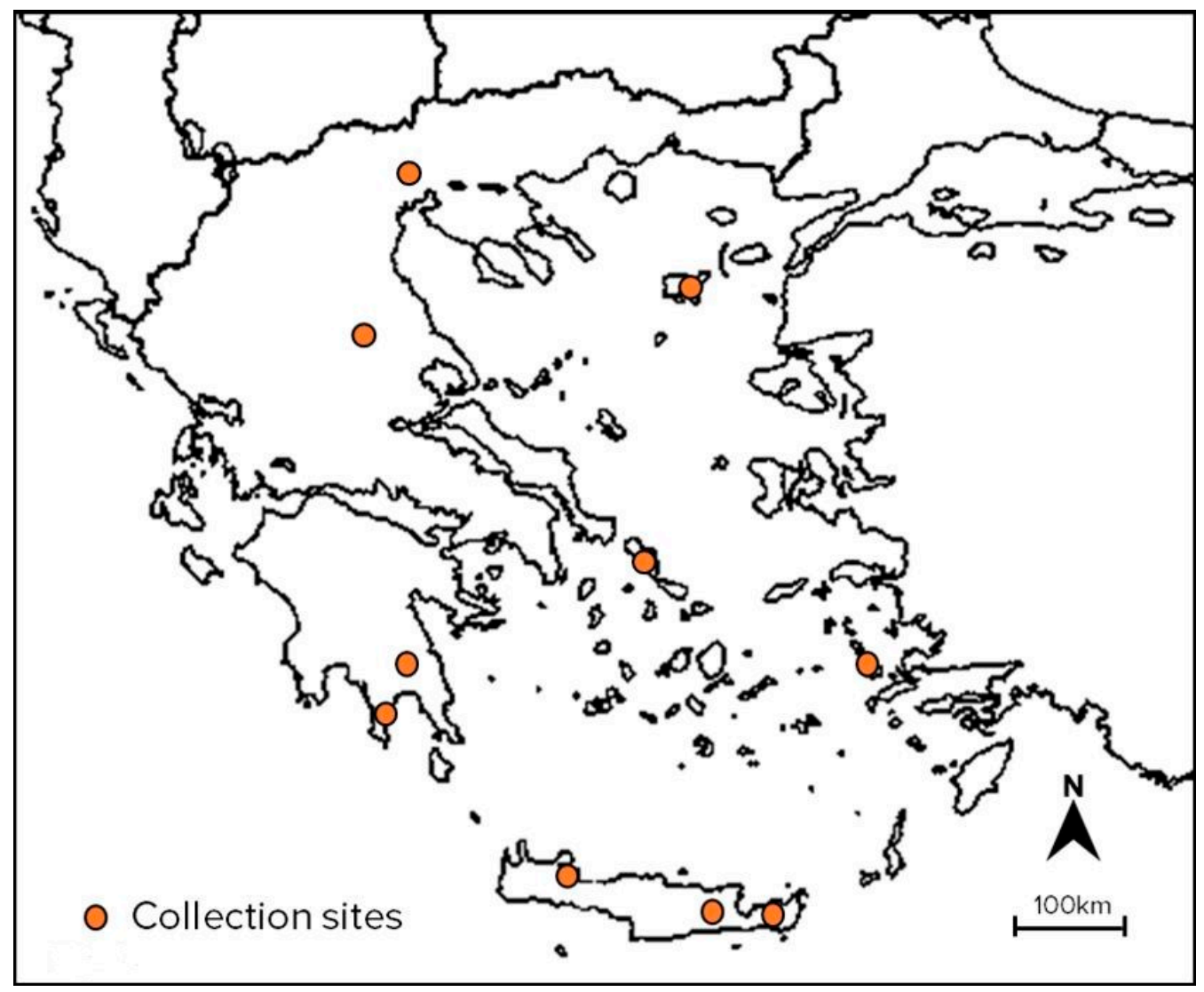

Figure 5. Map of collection areas of white lupin accessions used in the study (Google, n.d.). 
Table 3. Details on genotype, collection sites and origin, sample source, and sample type of the plant material.

\begin{tabular}{|c|c|c|c|c|}
\hline Accession & Collection Site/Origin & Genotype & Sample Type & Sample Site \\
\hline GR1 & Crete & Landrace & Cultivated area & Cultivated \\
\hline GR2 & Crete & Landrace & Cultivated area & Cultivated \\
\hline GR3 & Crete & Landrace & Farm storage & Cultivated \\
\hline GR4 & Crete & Landrace & Cultivated area & Cultivated \\
\hline GR5 & Leros & Landrace & Farm storage & Cultivated \\
\hline GR6 & Leros & Landrace & " & " \\
\hline GR7 & Lemnos & Landrace & “ & “ \\
\hline GR8 & Lemnos & Landrace & “ & “ \\
\hline GR9 & Lemnos & Landrace & “ & “ \\
\hline GR10 & Lemnos & Landrace & “ & “ \\
\hline GR11 & Lemnos & Landrace & “ & “ \\
\hline GR12 & Lemnos & Landrace & “ & “ \\
\hline GR13 & Macedonia & Landrace & “ & “ \\
\hline GR14 & Macedonia & Landrace & “ & “ \\
\hline GR15 & Mani & Landrace & “ & “ \\
\hline GR16 & Mani & Landrace & “ & “ \\
\hline GR17 & Mani & Landrace & “ & “ \\
\hline GR18 & Mani & Landrace & “ & “ \\
\hline GR19 & Crete & Landrace & “ & “ \\
\hline GR20 & Crete & Landrace & “ & “ \\
\hline GR21 & Lakonia & Landrace & “ & “ \\
\hline GR22 & Lakonia & Landrace & “ & “ \\
\hline GR23 & Andros & Landrace & Uncultivated disturbed area & Wild \\
\hline GR24 & Andros & Landrace & Uncultivated and undisturbed area & Wild \\
\hline GR25 & Andros & Landrace & “ & $" \prime$ \\
\hline GR26 & Andros & Landrace & Uncultivated and disturbed area & Wild \\
\hline GR27 & Andros & Landrace & " & " \\
\hline GR28 & Andros & Landrace & " & “ \\
\hline GR29 & Thessaly & Breeding Line & Agricultural institute & Breeder's line \\
\hline GRKML & Thessaly & Breeding Line & " & " \\
\hline GRKAL & Thessaly & Breeding Line & “ & “ \\
\hline GRKCA & Thessaly & Breeding Line & “ & “ \\
\hline Energy & France & Cultivar * & Company & Cultivated \\
\hline Magnus & France & Cultivar & "1 & " \\
\hline Orus & France & Cultivar & “ & “ \\
\hline FAS & EU & Cultivar & “ & “ \\
\hline Estoril & Portugal & Cultivar & “ & “ \\
\hline Ulysse & France & Cultivar & “ & “ \\
\hline Sulimo & France & Cultivar & “ & “ \\
\hline Figaro & France & Cultivar & “ & “ \\
\hline Multitalia & Italy & Cultivar & “ & “ \\
\hline Tennis & Italy & Cultivar & “ & “ \\
\hline Amiga & France/Czech Republic & Cultivar & “ & “ \\
\hline Frieda & Germany & Cultivar & “ & “ \\
\hline Celina & Germany & Cultivar & “ & “ \\
\hline
\end{tabular}

* According to the European Plant Variety Database (PVD, 2021).

\subsection{Estimation of Genetic Diversity}

\subsubsection{Seed Morphological Diversity Analysis}

The Thousand Seed Weight (TSW) was calculated, based on the weight of 100 seeds in three independent replicates. Seed morphological diversity was estimated, by subjecting 10 seeds of each sample to examination according to standard criteria (IBPGR 1981) using image analysis as previously described [61]. Calculation of the Euclidean distance, Principal Component Analysis (PCA), UPGMA dendrogram, Wilks' Lambda test and Multivariate Analysis of Variance (MANOVA) between all 45 samples were performed, using the XLSTAT software (Data Analysis and Statistical Solution for Microsoft Excel, Addinsoft, Paris, France 2017). 


\subsubsection{PCR and SSR-HRM Analysis}

For every accession, the molecular genetic diversity was assessed on bulked samples of 5 individuals. Genomic DNA was extracted from seeds, applying the QIAGEN DNeasy Plant Pro Kit (Qiagen, Hilden, Germany). The yield of the extracted DNA was estimated with Qbit 4 Fluorometer (Thermo Fisher Scientific, Waltham, MA, USA) and normalized to $5 \mathrm{ng} / \mu \mathrm{L}$ for downstream applications. Genotypic analysis was performed using 6 polymorphic microsatellite markers (online Supplementary Table S1), based on reports by Nelson et al. [62]. PCR amplification reactions and High-Resolution Melting Analysis were carried out on LightCycler ${ }^{\circledR} 96$ (Roche Diagnostics Gmbh, Mannheim, Germany), using KAPA HRM FAST PCR Kit (KAPA Biosystems, Wilmington, MA, USA), in a total reaction volume of $12 \mu \mathrm{L}$, containing $5 \mathrm{ng}$ genomic DNA template, 1X KAPA HRM FAST Master Mix, $0.2 \mu \mathrm{M}$ of each primer, $2.5 \mathrm{mM} \mathrm{MgCl}_{2}$, and PCR-grade $\mathrm{H}_{2} \mathrm{O}$. The PCR amplification program constitutes an initial denaturation step at $94^{\circ} \mathrm{C} / 4 \mathrm{~min}$, followed by 35 cycles of denaturation at $94{ }^{\circ} \mathrm{C} / 30 \mathrm{~s}$, primer annealing at $58^{\circ} \mathrm{C}$, and extension at $72{ }^{\circ} \mathrm{C} / 40 \mathrm{~s}$. The HRM step includes denaturation at $95^{\circ} \mathrm{C} / 60 \mathrm{~s}$, annealing at $40^{\circ} \mathrm{C} / 60 \mathrm{~s}$, gradual denaturation from $65^{\circ} \mathrm{C}$ to $97^{\circ} \mathrm{C}$ by $0.05^{\circ} \mathrm{C} / \mathrm{s}$, and fluorescence detection 20 times per ${ }^{\circ} \mathrm{C}$.

\subsection{Analysis of Molecular Genetic Relationships}

The samples were assigned to groups, according to the amplicons melting temperature $(\mathrm{Tm})$, the shape of the normalized melting curves, and the difference plots, generated by the HRM analysis, with different groups denoting dissimilar genetic profiles, and a binary matrix was formed, for further analyses. Genetic distances between all 45 accessions were calculated based on Nei's genetic distance [63], and a dissimilarity matrix was generated using GenAlEx 6.5, which was subjected to tree construction, under the Unweighted Pair Group Method Analysis (UPGMA), using MEGA X [64]. Additionally, Principal Coordinates Analysis (PCoA) was carried out on GenAlEx 6.5. The Polymorphic Information Content of the SSR markers was calculated according to Smith et al. (1997). Potential correlation of the genetic distances calculated by morphological and molecular diversity, was investigated through Mantel's test. The association of the molecular markers to the seed morphological traits was estimated through multiple linear regression analysis, using IBM SPSS Statistics for Windows Version 24.0 (IBM Corp., Armonk, NY, USA).

\subsection{Germplasm Molecular Characterization on Anthracnose Resistance, Vernalization Responsiveness amd Alkaloid Biosynthesis}

Germplasm evaluation on agronomically important traits, was addressed by investigating for the presence of alleles, that control low alkaloid content, resistance to anthracnose and vernalization requirement, applying a set of recently developed, specifically designed dCAPS molecular markers (Table 4) $[18,19,48]$. PCR amplification reactions were carried out on Veriti Dx Thermal Cycler (Applied Biosystems ${ }^{\circledR}$, Waltham, MA, USA), using KAPA Taq ReadyMix PCR Kit (Kapa Biosystems, Wilmington, MA, USA) in a total reaction volume of $15 \mu \mathrm{L}$, containing $20 \mathrm{ng}$ genomic DNA, 1X KAPA Taq ReadyMix Mix, $0.2 \mu \mathrm{M}$ of each primer, $1.5 \mathrm{mM} \mathrm{MgCl}_{2}$, and PCR-grade $\mathrm{H}_{2} \mathrm{O}$. PCR amplification was performed under the following conditions: initial denaturation at $94{ }^{\circ} \mathrm{C}$ for $4 \mathrm{~min}$, followed by 35 cycles of denaturation at $94{ }^{\circ} \mathrm{C}$ for $30 \mathrm{~s}$, annealing for $30 \mathrm{~s}$, extension at $72{ }^{\circ} \mathrm{C}$ for $30 \mathrm{~s}$, and final extension at $72{ }^{\circ} \mathrm{C}$ for $4 \mathrm{~min}$. In order to detect the presence of the target allele of each marker, all samples were subjected to post-PCR restriction enzyme digestion, following the appropriate protocol provided by New England BioLabs (Ipswich, MA, USA). The presence or absence of the target alleles was then verified by $3 \%$ agarose gel electrophoresis (1× TAE) on 100 volts for $40 \mathrm{~min}$. 
Table 4. Molecular markers used for germplasm characterization on agronomic traits.

\begin{tabular}{|c|c|c|c|}
\hline Trait & Molecular Marker & Validated Enzyme & Phenotype: Allele (bp) \\
\hline QA content & LAGI01_35805_F1_R1 & BclI & $\begin{array}{l}\text { low QA content: } 197 \\
\text { high QA content: } 108,89\end{array}$ \\
\hline \multirow{2}{*}{ Anthracnose resistance } & TP222136 & CviKI-1 & $\begin{array}{l}\text { Anthr. susceptible: } 168,27,15 \\
\text { Anthr. resistant: } 183.27\end{array}$ \\
\hline & ТР338761 & SchI & $\begin{array}{c}\text { Anthr. susceptible: } 83,28 \\
\text { Anthr. resistant: } 64,47\end{array}$ \\
\hline \multirow{3}{*}{ Vernalization requirement } & GI-F1 & AciI & $\begin{array}{l}\text { vernalization unresponsive: } 127,30 \\
\text { vernalization responsive: } 157\end{array}$ \\
\hline & FTa1-F1 & - & $\begin{array}{c}\text { vernalization unresponsive: } 2036 \\
\text { vernalization responsive: } 1353\end{array}$ \\
\hline & SEP3-F1 & TaqI & $\begin{array}{l}\text { vernalization unresponsive: } 122,23 \\
\text { vernalization responsive: } 145\end{array}$ \\
\hline
\end{tabular}

\subsection{Extraction of Alkaloids and Profiling by HPLC-HRMS-Mass Spectrometry}

Sample preparation was adopted from a recently published study [65], incorporating minor modifications. Briefly, a mixture of $0.5 \mathrm{~g}$ of pulverized seeds with a $\mathrm{MeOH}: \mathrm{H}_{2} \mathrm{O}$, $4: 1(v / v)$ solution $(10 \mathrm{~mL})$ containing $0.1 \%$ formic acid was vortex mixed $(1 \mathrm{~min})$, and then extracted with an ULTRA-TURRAX homogenizer (Ika T25, Staufen, Germany) for $4 \mathrm{~min}$ in total (4 rounds of $1 \mathrm{~min}$, applying a $15 \mathrm{~s}$ break between each round) at $4{ }^{\circ} \mathrm{C}$. Consequently, after centrifugation the supernatant was filtered with Nylon filters $(0.22 \mu \mathrm{m})$, collected, and a 1:100 dilution was applied to furnish the final extract working solution. The latter was injected to the UHPLC-HRMS system (Ultra-High Performance Liquid Chromatography) — coupled to Q-Orbitrap High Resolution Mass Spectrometry.

Samples were analyzed with a Dionex Ultimate 3000 UHPLC system (Thermo Fisher Scientific, San Jose, CA, USA) linked to Q-Exactive Orbitrap HRMS (Thermo Fisher Scientific, San Jose, CA, USA). A Hypersil Gold UPLC C18 $(2.1 \times 100 \mathrm{~mm}, 1.9 \mu \mathrm{m})$ reversed phased column (Thermo Fisher Scientific, San Jose, CA, USA) was used for the separation that was maintained at $40{ }^{\circ} \mathrm{C}$. Gradient elution of analytes was carried out with aqueous $0.1 \%(v / v)$ formic acid (A) and $0.1 \%(v / v)$ formic acid in acetonitrile (B). The gradient elution was: $\mathrm{T}=0 \mathrm{~min}, 5 \% \mathrm{~B} ; \mathrm{T}=3 \mathrm{~min}, 5 \% \mathrm{~B}, \mathrm{~T}=21 \mathrm{~min}, 95 \% \mathrm{~B}, \mathrm{~T}=23 \mathrm{~min}, 95 \% \mathrm{~B}$, $\mathrm{T}=24 \mathrm{~min}, 5 \% \mathrm{~B} ; \mathrm{T}=30 \mathrm{~min}, 5 \% \mathrm{~B}$. The flow rate was $0.22 \mathrm{~mL} / \mathrm{min}$ and the injection volume $3 \mu \mathrm{L}$. The ionization was performed using heated electrospray ionization (HESI), in the positive ion mode. The conditions for the HRMS were set as follows: capillary temperature, $350^{\circ} \mathrm{C}$; spray voltage, $2.7 \mathrm{kV}$; S-lense Rf level, $50 \mathrm{~V}$; sheath gas flow, 40 arb. units; aux gas flow, 5 arb. Units; aux. gas heater Temperature, $50{ }^{\circ} \mathrm{C}$. The analysis was performed in the full scan ion mode, applying a resolution of 70,000, with a mass range of $100-1200 \mathrm{~m} / \mathrm{z}$ while acquisition of the mass spectra was performed in the centroid mode.

All reagents and chemicals used were of analytical grade. Acetonitrile (I), methanol $(\mathrm{MeOH})$, and formic acid of LC-MS grade were obtained from Merck (Darmstadt, Germany). Ultra-pure water was produced from SG Milipore apparatus. Nylon filters $(0.22 \mu \mathrm{m})$ were obtained from Macherey-Nagel (Dueren, Germany).

Post-acquisition data analyses were performed using Compound Discoverer 2.1 software (Thermo Fisher Scientific, San Jose, CA, USA). The software was used to manipulate data and apply procedures of chromatographic processing region selection, application of baseline correction, peak detection, deconvolution, peak alignment, deisotoping and gap filling. For the putative annotation of the compounds a custom library was prepared based on the expected compounds of the genus of Lupinus using as a source the Dictionary of Natural Products applying a tolerance of $5 \mathrm{~m} / \mathrm{z}$.

\section{Conclusions}

Legumes are pivotal for the sustainability of farming and food systems, by promoting soil fertility and environmental protection, in addition to food security. White lupin 
represents an emerging crop, providing both agricultural and nutritional benefits, yet in demand of extensive breeding. This study highlighted the presence of highly variable Mediterranean landraces, concealing potentially valuable genetic loci for adaptation in the local conditions, important for lupin breeding. The landraces evaluated are considered bitter-seeded, as they possess high-alkaloid content and probably the relative allele(s) in their genome. Therefore, they require debittering processing prior to consumption. Further breeding, addressing the reduction of high-alkaloid seed content, could yield lupin seeds ready-to-use in food industry and in forage as well. Moreover, 8 landraces were identified harboring the SEPALLATA 3 vernalization unresponsiveness-allele, as well as 2 landraces possessing both anthracnose-resistance alleles. These landraces could provide a significant genetic resource, to be harnessed in white lupin breeding programs. Expansion of white lupin cultivation to various hardiness zones, would promote legume reintroduction to the European farming systems, endorsing agriculture and environment sustainability in support of green farming.

Supplementary Materials: The following are available online at https:/ /www.mdpi.com/article/10 $.3390 /$ plants10112403/s1, Table S1: Primers of molecular markers used for estimating the genetic diversity, Table S2: Sixteen alkaloids were tentatively annotated in all the white lupin seeds extracts after the UHPLC-HRMS (Orbitrap) analysis, using a custom library based on the genus Lupinus and applying tolerance of $5 \mathrm{~m} / \mathrm{z}$, Figure S1: Representative chromatogram of a white lupin seed extract sample after the UHPLC-HRMS (Orbitrap) analysis, in the positive ion mode, Figure S2: Alkaloids chemical profile of selected seed extracts, Figure S3: Representative seeds of the GR24 landrace, Figure S4: Representative seeds of the GR25 landrace, Figure S5: Representative seeds of the GR27 landrace, Figure S6: Representative seeds of the GR28 landrace.

Author Contributions: Conceptualization: P.V.M.; Methodology: I.Z., E.B., K.M.K., K.M. and P.V.M.; Project Administration: P.V.M.; Investigation: I.Z., A.N.P., E.B. and K.M.K.; Formal Analysis: I.Z., A.N.P., E.B., K.M.K. and K.M.; Funding acquisition: P.V.M.; Resources: K.M. and P.V.M.; Writingoriginal draft: I.Z.; Writing—review and editing: I.Z., A.N.P. and P.V.M. All authors have read and agreed to the published version of the manuscript.

Funding: This research has been co-financed by the European Regional Development Fund of the European Union and Greek national funds through the Operational Program Competitiveness, Entrepreneurship and Innovation, under the call RESEARCH-CREATE-INNOVATE (project code: T1EDK-04448).

Data Availability Statement: The data that support the findings of this study are available from the corresponding author upon reasonable request.

Acknowledgments: We would like to express our sincere appreciation to Christine Arncken-Karutz from the Research Institute of Organic Agriculture (FiBL) for providing valuable information of white lupin varieties. To Frederik Schirrmacher, Product Manager Cereals \& Grain of Deutsche Saatveredelung AG, for providing samples of the new release L. albus varieties Frieda and Celina and to P. Bebeli from the Agricultural University of Athens for sharing lupin genetic material. We declare that the work presented in this paper is the original.

Conflicts of Interest: The authors declare no conflict of interest.

\section{References}

1. Eastwood, R.J.; Drummond, C.S.; Schifino-Wittmann, M.T.; Hughes, C.E. Diversity and Evolutionary History of Lupins-Insights from New Phylogenies. In Lupins for health and wealth, Proceedings of the 12th International Lupin Conference, Fremantle, Australia, 14-18 September 2008; Palta, J.A., Berger, J.B., Eds.; International Lupin Association: Canterbury, New Zealand; pp. 346-354, ISBN 0-86476-153-8.

2. Tirdil'ová, I.; Vollmannová, A.; Siekel, P.; Zetochová, E.; Čéryová, S.; Trebichalský, P. Selected legumes as a source of valuable substances in human nutrition. J. Food Nutr. Res. 2020, 59, 193-201.

3. Prusinski, J. White lupin (Lupinus albus L.)-Nutritional and health values in human nutrition-A review. Czech J. Food Sci. 2017, 35, 95-105. [CrossRef]

4. Shu, L.; Shen, J.; Rengel, Z.; Tang, C.; Zhang, F.; Cawthray, G.R. Formation of cluster roots and citrate exudation by Lupinus albus in response to localized application of different phosphorus sources. Plant Sci. 2007, 172, 1017-1024. [CrossRef] 
5. Stagnari, F.; Maggio, A.; Galieni, A.; Pisante, M. Multiple benefits of legumes for agriculture sustainability: An overview. Chem. Biol. Technol. Agric. 2017, 4, 1-13. [CrossRef]

6. Kalembasa, S.; Szukała, J.; Faligowska, A.; Kalembasa, D.; Symanowicz, B.; Becher, M.; Gebus-Czupyt, B. Quantification of biologically fixed nitrogen by white lupin (Lupins albus L.) and its subsequent uptake by winter wheat using the 15n isotope dilution method. Agronomy 2020, 10, 1392. [CrossRef]

7. Lambers, H.; Martinoia, E.; Renton, M. Plant adaptations to severely phosphorus-impoverished soils. Curr. Opin. Plant Biol. 2015, 25, 23-31. [CrossRef]

8. Jimenez-Lopez, J.C.; Singh, K.B.; Clemente, A.; Nelson, M.N.; Ochatt, S.; Smith, P.M.C. Editorial: Legumes for Global Food Security. Front. Plant Sci. 2020, 11, 926. [CrossRef] [PubMed]

9. Abraham, E.M.; Ganopoulos, I.; Madesis, P.; Mavromatis, A.; Mylona, P.; Nianiou-Obeidat, I.; Parissi, Z.; Polidoros, A.; Tani, E.; Vlachostergios, D. The use of lupin as a source of protein in animal feeding: Genomic tools and breeding approaches. Int. J. Mol. Sci. 2019, 20, 851. [CrossRef]

10. Struti, D.I.; Mierlita, D.; Pop, I.M.; Ladosi, D.; Papuc, T. Evaluation of the chemical composition and nutritional quality of dehulled lupin seed meal (Lupinus spp. L.) and its use for monogastrics animal nutrition: A review. Sci. Pap. Ser. D Anim. Sci. Int. Sess. Sci. Commun. Fac. Anim. Sci. 2020, 63, 92-105.

11. FAO. FAOSTAT Statistical Database. Crops and Livestock Products. 2019. Available online: https://www.fao.org/faostat/en/ \#data/QCL (accessed on 28 September 2021).

12. Gresta, F.; Wink, M.; Prins, U.; Abberton, M.; Capraro, J.; Scarafoni, A.; Hill, G. Lupins in European cropping systems. In Legumes Cropping Systems; Murphy-Bokern, D., Stoddard, F.L., Watson, C.A., Eds.; CABI: Wallingford, UK, 2017; pp. 88-108. [CrossRef]

13. Rybiński, W.; Święcicki, W.; Bocianowski, J.; Börner, A.; Starzycka-Korbas, E.; Starzycki, M. Variability of fat content and fatty acids profiles in seeds of a Polish white lupin (Lupinus albus L.) collection. Genet. Resour. Crop Evol. 2018, 65, 417-431. [CrossRef]

14. Ksiazkiewicz, M.; Nazzicari, N.; Yang, H.; Nelson, M.N.; Renshaw, D.; Rychel, S.; Ferrari, B.; Carelli, M.; Tomaszewska, M.; Stawiński, S.; et al. A high-density consensus linkage map of white lupin highlights synteny with narrow-leafed lupin and provides markers tagging key agronomic traits. Sci. Rep. 2017, 7, 1-15. [CrossRef]

15. Frick, K.M.; Kamphuis, L.G.; Siddique, K.H.M.; Singh, K.B.; Foley, R.C. Quinolizidine Alkaloid Biosynthesis in Lupins and Prospects for Grain Quality Improvement. Front. Plant Sci. 2017, 8, 87. [CrossRef] [PubMed]

16. Kroc, M.; Rybiński, W.; Wilczura, P.; Kamel, K.; Kaczmarek, Z.; Barzyk, P.; Święcicki, W. Quantitative and qualitative analysis of alkaloids composition in the seeds of a white lupin (Lupinus albus L.) collection. Genet. Resour. Crop Evol. 2017, 64, 1853-1860. [CrossRef]

17. Hufnagel, B.; Soriano, A.; Taylor, J.; Divol, F.; Kroc, M.; Sanders, H.; Yeheyis, L.; Nelson, M.; Péret, B. Pangenome of white lupin provides insights into the diversity of the species. Plant Biotechnol. J. 2021. [CrossRef]

18. Rychel, S.; Książkiewicz, M.; Tomaszewska, M.; Bielski, W.; Wolko, B. Flowering Locus T, Gigantea, Sepallata, and Frigida homologs are candidate genes involved in white lupin (Lupinus albus L.) early flowering. Mol. Breed. 2019, 39, 1-17. [CrossRef]

19. Rychel-Bielska, S.; Nazzicari, N.; Plewiński, P.; Bielski, W.; Annicchiarico, P.; Książkiewicz, M. Development of PCR-based markers and whole-genome selection model for anthracnose resistance in white lupin (Lupinus albus L.). J. Appl. Genet. 2020, 61, 531-545. [CrossRef]

20. Annicchiarico, P.; Nazzicari, N.; Ferrari, B.; Harzic, N.; Carroni, A.M.; Romani, M.; Pecetti, L. Genomic prediction of grain yield in contrasting environments for white lupin genetic resources. Mol. Breed. 2019, 39, 1-12. [CrossRef]

21. Arief, O.M.; Pang, J.; Shaltout, K.H.; Lambers, H. Performance of two Lupinus albus L. cultivars in response to three soil pH levels. Exp. Agric. 2020, 56, 321-330. [CrossRef]

22. Sloat, L.L.; Davis, S.J.; Gerber, J.S.; Moore, F.C.; Ray, D.K.; West, P.C.; Mueller, N.D. Climate adaptation by crop migration. Nat. Commun. 2020, 11, 1-9. [CrossRef] [PubMed]

23. Brogli, R.; Sørland, S.L.; Kröner, N.; Schär, C. Causes of future Mediterranean precipitation decline depend on the season. Environ. Res. Lett. 2019, 14, 114017. [CrossRef]

24. Sakellariou, M.; Psiloglou, B.E.; Giannakopoulos, C.; Mylona, P.V. Integration of Abandoned Lands in Sustainable Agriculture: The Case of Terraced Landscape Re-Cultivation in Mediterranean Island Conditions. Land 2021, 10, 457. [CrossRef]

25. Tramblay, Y.; Koutroulis, A.; Samaniego, L.; Vicente-Serrano, S.M.; Volaire, F.; Boone, A.; Le Page, M.; Llasat, M.C.; Albergel, C.; Burak, S.; et al. Challenges for drought assessment in the Mediterranean region under future climate scenarios. Earth-Sci. Rev. 2020, 210, 103348. [CrossRef]

26. Yu, J.; Jiang, M.; Guo, C. Crop pollen development under drought: From the phenotype to the mechanism. Int. J. Mol. Sci. 2019, 20, 1550. [CrossRef]

27. Rering, C.C.; Franco, J.G.; Yeater, K.M.; Mallinger, R.E. Drought stress alters floral volatiles and reduces floral rewards, pollinator activity, and seed set in a global plant. Ecosphere 2020, 11, e03254. [CrossRef]

28. Descamps, C.; Quinet, M.; Jacquemart, A.L. The effects of drought on plant-pollinator interactions: What to expect? Environ. Exp. Bot. 2021, 182, 104297. [CrossRef]

29. Brás, T.A.; Seixas, J.; Carvalhais, N.; Jägermeyr, J. Severity of drought and heatwave crop losses tripled over the last five decades in Europe. Environ. Res. Lett. 2021, 16, 065012. [CrossRef]

30. Cohen, I.; Zandalinas, S.I.; Huck, C.; Fritschi, F.B.; Mittler, R. Meta-analysis of drought and heat stress combination impact on crop yield and yield components. Physiol. Plant. 2021, 171, 66-76. [CrossRef] [PubMed] 
31. Rychel-Bielska, S.; Surma, A.; Bielski, W.; Kozak, B.; Galek, R.; Książkiewicz, M. Quantitative control of early flowering in white lupin (Lupinus albus L.). Int. J. Mol. Sci. 2021, 22, 3856. [CrossRef]

32. Falconi, C.E.; Visser, R.G.F.; Van Heusden, S. Influence of plant growth stage on resistance to anthracnose in Andean lupin (Lupinus mutabilis). Crop Pasture Sci. 2015, 66, 729-734. [CrossRef]

33. Annicchiarico, P.; Barrett, B.; Brummer, E.C.; Julier, B.; Marshall, A.H. Achievements and Challenges in Improving Temperate Perennial Forage Legumes. Crit. Rev. Plant Sci. 2015, 34, 327-380. [CrossRef]

34. Talhinhas, P.; Baroncelli, R.; Le Floch, G. Anthracnose of Lupins Caused by Colletotrichum Lupini: A Recent Disease and a Successful Worldwide Pathogen. J. Plant Pathol. 2016, 98, 5-14. [CrossRef]

35. Adhikari, K.N.; Buirchell, B.J.; Thomas, G.J.; Sweetingham, M.W.; Yang, H. Identification of anthracnose resistance in Lupinus albus L. and its transfer from landraces to modern cultivars. Crop Pasture Sci. 2009, 60, 472. [CrossRef]

36. Thomas, G.J.; Sweetingham, M.W.; Yang, H.A.; Speijers, J. Effect of temperature on growth of Colletotrichum lupini and on anthracnose infection and resistance in lupins. Australas. Plant Pathol. 2008, 37, 35-39. [CrossRef]

37. Msairi, S.; Chliyeh, M.; Touhami, A.O.; El Alaoui, A.; Selmaoui, K.; Benkirane, R.; Filali-Maltouf, A.; El Modafar, C.; Douira, A. First report of colletotrichum lupini causing anthracnose disease on the olive fruits in Morocco. Plant Cell Biotechnol. Mol. Biol. 2020, 21, 1-11.

38. Phan, H.T.T.; Ellwood, S.R.; Adhikari, K.; Nelson, M.N.; Oliver, R.P. The first genetic and comparative map of white lupin (Lupinus albus L.): Identification of QTLs for anthracnose resistance and flowering time, and a locus for alkaloid content. DNA Res. 2007, 14, 59-70. [CrossRef] [PubMed]

39. Jacob, I.; Feuerstein, U.; Heinz, M.; Schott, M.; Urbatzka, P. Evaluation of new breeding lines of white lupin with improved resistance to anthracnose. Euphytica 2017, 213, 236. [CrossRef]

40. Alkemade, J.; Messmer, M.; Arncken, C.; Leska, A.; Annicchiarico, P.; Nazzicari, N.; Książkiewicz, M.; Voegele, R.T.; Finckh, M.; Hohmann, P. A high-throughput phenotyping tool to identify field-relevant anthracnose resistance in white lupin. Plant Dis. 2021, 105, 1719-1727. [CrossRef] [PubMed]

41. Nelson, M.N.; Książkiewicz, M.; Rychel, S.; Besharat, N.; Taylor, C.M.; Wyrwa, K.; Jost, R.; Erskine, W.; Cowling, W.A.; Berger, J.D.; et al. The loss of vernalization requirement in narrow-leafed lupin is associated with a deletion in the promoter and de-repressed expression of a Flowering Locus T (FT) homologue. New Phytol. 2017, 213, 220-232. [CrossRef]

42. Atnaf, M.; Yao, N.; Martina, K.; Dagne, K.; Wegary, D.; Tesfaye, K. Molecular genetic diversity and population structure of Ethiopian white lupin landraces: Implications for breeding and conservation. PLoS ONE 2017, 12, e0188696. [CrossRef] [PubMed]

43. Kroc, M.; Tomaszewska, M.; Czepiel, K.; Bitocchi, E.; Oppermann, M.; Neumann, K.; Guasch, L.; Bellucci, E.; Alseekh, S.; Graner, A.; et al. Towards Development, Maintenance, and Standardized Phenotypic Characterization of Single-Seed-Descent Genetic Resources for Lupins. Curr. Protoc. 2021, 1, e191. [CrossRef]

44. Beyene, C. Genetic variation among white lupin (Lupinus albus L.) landraces from Northwestern and Southern Ethiopia for agronomic traits and nutrient contents of grain. J. Plant Breed. Crop Sci. 2020, 12, 156-169. [CrossRef]

45. Plewiński, P.; Książkiewicz, M.; Rychel-Bielska, S.; Rudy, E.; Wolko, B. Candidate domestication-related genes revealed by expression quantitative trait loci mapping of narrow-leafed lupin (Lupinus angustifolius L.). Int. J. Mol. Sci. 2019, 20, 5670. [CrossRef] [PubMed]

46. Annicchiarico, P.; Romani, M.; Pecetti, L. White lupin (Lupinus albus) variation for adaptation to severe drought stress. Plant Breed. 2018, 137, 782-789. [CrossRef]

47. Berger, J.D.; Shrestha, D.; Ludwig, C. Reproductive strategies in mediterranean legumes: Trade-offs between phenology, seed size and vigor within and between wild and domesticated lupinus species collected along aridity gradients. Front. Plant Sci. 2017, 8, 548. [CrossRef]

48. Rychel, S.; Książkiewicz, M. Development of gene-based molecular markers tagging low alkaloid pauper locus in white lupin (Lupinus albus L.). J. Appl. Genet. 2019, 60, 269-281. [CrossRef]

49. Di Santo, L.N.; Polgar, M.; Nies, S.; Hodgkiss, P.; Canning, C.A.; Wright, J.W.; Hamilton, J.A. Seed morphological traits as a tool to quantify variation maintained in ex situ collections: A case study in Pinus torreyana. AoB Plants 2021, 13, 58. [CrossRef]

50. Lagunes-Espinoza, L.C.; Huyghe, C.; Papineau, J. Genetic variation for pod wall proportion in Lupinus albus L. Plant Breed. 2000, 119, 421-425. [CrossRef]

51. González-Andrés, F.; Casquero, P.A.; San-Pedro, C.; Hernández-Sánchez, E. Diversity in White Lupin (Lupinus albus L.) Landraces from Northwest Iberianplateau. Genet. Resour. Crop Evol. 2007, 54, 27-44. [CrossRef]

52. Raman, R.; Cowley, R.B.; Raman, H.; Luckett, D.J. Analyses Using SSR and DArT Molecular Markers Reveal that Ethiopian Accessions of White Lupin (Lupinus albus L.) Represent a Unique Genepool. Open J. Genet. 2014, 04, 87-98. [CrossRef]

53. El-Harty, E.; Ashrie, A.; Ammar, M.; Alghamdi, S. Genetic variation among egyptian white lupin (Lupinus albus L.) genotypes. Turk. J. Field Crop. 2016, 21, 148-155. [CrossRef]

54. Casañas, F.; Simó, J.; Casals, J.; Prohens, J. Toward an evolved concept of landrace. Front. Plant Sci. 2017, 8, 145. [CrossRef]

55. Coomes, O.T.; McGuire, S.J.; Garine, E.; Caillon, S.; McKey, D.; Demeulenaere, E.; Jarvis, D.; Aistara, G.; Barnaud, A.; Clouvel, P.; et al. Farmer seed networks make a limited contribution to agriculture? Four common misconceptions. Food Policy 2015, 56, 41-50. [CrossRef]

56. Fekadu Gemede, H. Antinutritional Factors in Plant Foods: Potential Health Benefits and Adverse Effects. Int. J. Nutr. Food Sci. 2014, 3, 284. [CrossRef] 
57. Lin, R.; Renshaw, D.; Luckett, D.; Clements, J.; Yan, G.; Adhikari, K.; Buirchell, B.; Sweetingham, M.; Yang, H. Development of a sequence-specific PCR marker linked to the gene "pauper" conferring low-alkaloids in white lupin (Lupinus albus L.) for marker assisted selection. Mol. Breed. 2009, 23, 153-161. [CrossRef]

58. Shavrukov, Y.; Kurishbayev, A.; Jatayev, S.; Shvidchenko, V.; Zotova, L.; Koekemoer, F.; De Groot, S.; Soole, K.; Langridge, P. Early flowering as a drought escape mechanism in plants: How can it aid wheat production? Front. Plant Sci. 2017, 8, 1950. [CrossRef]

59. Annicchiarico, P.; Harzic, N.; Carroni, A.M. Adaptation, diversity, and exploitation of global white lupin (Lupinus albus L.) landrace genetic resources. Field Crop. Res. 2010, 119, 114-124. [CrossRef]

60. Noffsinger, S.L.; Van Santen, E. Evaluation of Lupinus albus L. germplasm for the southeastern USA. Crop Sci. 2005, 45, 1941-1950. [CrossRef]

61. Tsanakas, G.F.; Mylona, P.V.; Koura, K.; Gleridou, A.; Polidoros, A.N. Genetic diversity analysis of the Greek lentil (Lens culinaris) landrace "Eglouvis" using morphological and molecular markers. Plant Genet. Resour. Charact. Util. 2018, 16, 469-477. [CrossRef]

62. Nelson, M.N.; Phan, H.T.T.; Ellwood, S.R.; Moolhuijzen, P.M.; Hane, J.; Williams, A.; O'Lone, C.E.; Fosu-Nyarko, J.; Scobie, M.; Cakir, M.; et al. The first gene-based map of Lupinus angustifolius L.-location of domestication genes and conserved synteny with Medicago truncatula. Theor. Appl. Genet. 2006, 113, 225-238. [CrossRef] [PubMed]

63. Nei, M.; Tajima, F.; Tateno, Y. Accuracy of estimated phylogenetic trees from molecular data-II. Gene frequency data. J. Mol. Evol. 1983, 19, 153-170. [CrossRef]

64. Kumar, S.; Stecher, G.; Li, M.; Knyaz, C.; Tamura, K. MEGA X: Molecular evolutionary genetics analysis across computing platforms. Mol. Biol. Evol. 2018, 35, 1547-1549. [CrossRef] [PubMed]

65. Ben Hassine, A.; Rocchetti, G.; Zhang, L.; Senizza, B.; Zengin, G.; Mahomoodally, M.F.; Ben-Attia, M.; Rouphael, Y.; Lucini, L.; El-Bok, S. Untargeted Phytochemical Profile, Antioxidant Capacity and Enzyme Inhibitory Activity of Cultivated and Wild Lupin Seeds from Tunisia. Molecules 2021, 26, 3452. [CrossRef] [PubMed] 